\title{
Is Mutation a Creative or Destructive Force in Evolution?
}

\section{William Beachly}

\author{
Hastings College, Department of Biology, 710 N. Turner Ave., Hastings NE 68901 USA \\ (wbeachly@hastings.edu)
}

\begin{abstract}
Most biologists would agree it is both, but how does one present the subtle distinctions to undergraduates in an engaging, exploratory, and data-generating laboratory exercise? AVIDA* offers a perfect platform, modeling virtual organisms as mutations occur at random locations in their genome. As in real haploid replicators, any mutation may or may not affect the fitness-correlated outcome of a successful phenotype but is more likely to be disruptive than constructive. However, without mutations, constructive new phenotypic functions are unable to evolve. With AVIDA, students set the rate of mutations and measure the latency in generations required for new functions to evolve. Each is like how a new biochemical pathway due to mutations in enzyme-coding genes allows a bacterial population to metabolize novel chemical substrates (either for energy or as defense against antibiotics.) A graphing of class data and simple statistical analysis tests the student-generated hypotheses regarding the relationship between mutation rate and innovations. This is illustrated with data obtained by freshman biology majors at Hastings College, as well as examples of novel AVIDA labs utilized in upper division courses and labs prepared by other educators and shared on the QUBEShub.

*AVIDA is a program designed by researchers at Michigan State University to evolve virtual organisms with genomes that mutate at random and can fortuitously develop Boolean functions that can help Avidians replicate, just as haploid organisms do. AVIDA-ED provides a free, and easy to learn, experimental platform for the study of evolution in which students can design experiments to test hypotheses that relate to actual organisms and real-world concerns such as antibiotic resistance.
\end{abstract}

Keywords: evolution, AVIDA, avidians, mutation rate

Link to Original Poster File: https://doi.org/10.37590/able.v41.poster58

\section{Mission, Review Process \& Disclaimer}

The Association for Biology Laboratory Education (ABLE) was founded in 1979 to promote information exchange among university and college educators actively concerned with teaching biology in a laboratory setting. The focus of ABLE is to improve the undergraduate biology laboratory experience by promoting the development and dissemination of interesting, innovative, and reliable laboratory exercises. For more information about ABLE, please visit http://www.ableweb.org/.

Advances in Biology Laboratory Education is the peer-reviewed publication of the conference of the Association for Biology Laboratory Education. Published articles and extended abstracts are evaluated and selected by a committee prior to presentation at the conference, peer-reviewed by participants at the conference, and edited by members of the ABLE Editorial Board. Published abstracts are evaluated and selected by a committee prior to presentation at the conference.

\section{Citing This Article}

Beachly W. 2020. Is mutation a creative or destructive force in evolution? Article 58 In: McMahon K, editor. Advances in biology laboratory educaiton Volume 41. Publication of the 41st Conference of the Association for Biology Laboratory Education (ABLE). https://doi.org/10.37590/able.v41.abs58

Compilation (C) 2020 by the Association for Biology Laboratory Education, ISBN 1-890444-17-0. All rights reserved. No part of this publication may be reproduced, stored in a retrieval system, or transmitted, in any form or by any means, electronic, mechanical, photocopying, recording, or otherwise, without the prior written permission of the copyright owner.

ABLE strongly encourages individuals to use the exercises in this volume in their teaching program. If this exercise is used solely at one's own institution with no intent for profit, it is excluded from the preceding copyright restriction, unless 
otherwise noted on the copyright notice of the individual chapter in this volume. Proper credit to this publication must be included in your laboratory outline for each use; a sample citation is given above. 